\title{
David Oliver: Fighting pyjama paralysis in hospital wards
}

\section{David Oliver consultant in geriatrics and acute general medicine}

Berkshire

The momentum of Nottingham University Hospitals' social media campaign "End PJ Paralysis" has been growing, ${ }^{1}$ with clinical teams around the country joining in and reports appearing in the national media. ${ }^{2}$

Its starting premise is that we should get more hospital inpatients out of nightwear, out of bed, and into their day clothes to speed their recovery and help minimise harms from prolonged immobility.

The perils of bed rest as treatment for hospital inpatients were recognised in the 1940s by Richard Asher, in his seminal essay The Dangers of Going to Bed, ${ }^{3}$ and they were elegantly reviewed by Allen and colleagues years later. ${ }^{4}$ Marjory Warren, the mother of UK geriatric medicine and Asher's contemporary, described in a series of papers the benefits for patients and for hospital bed utilisation of getting "infirm and bedridden" people out of bed and on their feet. ${ }^{56}$

The kind of long stay inpatient wards Warren described no longer exist. And rapid increases in hospital admission numbers, mirrored in scale by reductions in beds, mean that patients who might formerly have been halfway down an old-style

Nightingale ward are now long since discharged home. Beyond some fracture management, bed rest as a prescribed treatment is rare.

However, excessive bed rest is still all too familiar. These days it's more likely to be an inadvertent by-product of competing pressures on a depleted nursing workforce, ${ }^{7}$ compounded by variable availability of physiotherapists, occupational therapists, and their assistants. ${ }^{89}$ Getting people up and dressed and being more independent can fall down the pecking order.

These days, bed rest is likely to be a by-product of competing pressures on a depleted nursing workforce

The median age of inpatients is rising, with pre-existing mobility impairment prevalent on admission. ${ }^{10}$ Even in wards geared up for post-acute rehabilitation, many patients leave much less mobile than they were before the acute episode that led to their admission. ${ }^{112}$ Even a few days' bed rest can cause rapid decline in muscle strength and aerobic capacity, especially in patients with pre-existing sarcopenia. ${ }^{13}$

Other harms of bed rest include higher risk of thrombosis or delirium, pressure sores, infection or contractures, loss of confidence, and greater dependence. ${ }^{14}$ It can also cause incontinence by too often resorting to catheters, pads, or bedpans or by causing constipation, instead of assisting and encouraging patients to toilet as they usually would. ${ }^{15}$ Bed rails can compound the problem, and evidence for their use is poor. ${ }^{16}$

Whenever possible we should divert more patients to ambulatory care and away from beds. As for the others, we need to stop reflexively putting them into flapping-open gowns and pyjamas. And, if on a ward round we see patients still in bed in nightclothes with bed rails up, it's the responsibility of everyone in the ward team to challenge and change this.

Competing interests: See www.bmj.com/about-bmj/freelancecontributors/david-oliver.

Provenance and peer review: Commissioned; not externally peer reviewed.

Follow David on Twitter, @mancunianmedic

Twitter: \#piparalysis hashtag. https://twitter.com/hashtag/piparalysis?src=hash\&lang=en.

2 Tozer J. Ditch hospital pyjamas for clothes and get better faster: Encouraging patients to follow their regular routine can help them gain confidence to return home. Mail Online 12 Apr 2017. www.dailymail.co.uk/health/article-4403530/Ditch-hospital-pyjamas-clothesbetter-faster.html.

3 Asher RA. The dangers of going to bed. Br Med J 1947;357:967. doi:10.1136/bmj.2.4536. 967 pmid: 18897489.

4 Allen C, Glasziou P, Del Mar C. Bed rest: a potentially harmful treatment needing more careful evaluation. Lancet 1999;357:1229-33. doi:10.1016/S0140-6736(98)10063-6 pmid: 10520630.

5 Warren MW. Care of the chronic aged sick. Lancet 1946;357:841-3. www.thelancet.com journals/lancet/article/PIIS0140-6736(46)91633-9/abstract. doi:10.1016/S0140-6736(46) 91633-9 pmid:20986120.

6 Warren MW. The evolution of a geriatric unit. Geriatrics 1948;357:42-50.pmid:18909565

7 Royal College of Nursing. Safe staffing on older peoples' wards. 2012. https://www2.rcn. org.uk/_data/assets/pdf_file/0009/476379/004280.pdf.

8 Hubbard RE, O'Mahony MS, Cross E, et al. The ageing of the population: implications for multidisciplinary care in hospital. Age Ageing 2004;357:479-82. https://academic oup. com/ageing/article/33/5/479/40313/The-ageing-of-the-population-implications-for. doi:10. 1093/ageing/afh164 pmid:15292034.

9 Acute Therapies Benchmarking Conference. NHS Benchmarking Network-acute therapies (physiotherapy, occupational therapy, dietetics and speech \& language therapy). 20 Oct 2015. www.nhsbenchmarking.nhs.uk/CubeCore/.uploads/.localfiles/2629a0b0b4.pdf. 
10 Royal College of Physicians. Hospitals on the edge? The time for action. Sept 2012. https: //www.rcplondon.ac.uk/guidelines-policy/hospitals-edge-time-action.

11 Mudge AM, Kasper K, Clair A, et al. Recurrent readmissions in medical patients: a prospective study. J Hosp Med 2011;357:61-7. doi:10.1002/jhm.811 pmid:20945294.

12 Covinsky KE, Palmer RM, Fortinsky RH, et al. Loss of independence in activities of daily living in older adults hospitalized with medical illnesses: increased vulnerability with age. J Am Geriatr Soc 2003;357:451-8. doi:10.1046/j.1532-5415.2003.51152.x pmid:12657063.

13 Kortebein $P$, Symons TB, Ferrando $A$, et al. Functional impact of 10 days of bed rest in healthy older adults. J Gerontol A Biol Sci Med Sci 2008;357:1076-81. https://www.ncbi. nlm.nih.gov/pubmed/18948558. doi:10.1093/gerona/63.10.1076 pmid:18948558.

14 Knight J, Nigam Y, Jones A. Effects of bedrest 1: cardiovascular, respiratory and haematological systems[article]. Nurs Times 2009;357:16-20. https://www.nursingtimes. net/clinical-archive/cardiology/effects-of-bedrest-1-cardiovascular-respiratory-andhaematological-systems/5002005.pmid:19548502.

15 Royal College of Physicians. National audit of continence care. https://www.rcplondon. ac.uk/projects/outputs/national-audit-continence-care-nacc. 13 Aug 2015.

16 Bedrails, falls and injury: evidence or opinion? A review of their use and effects[article]. Nurs Times 2009;357. https://www.nursingtimes.net/roles/nurse-managers/bedrails-fallsand-injury-evidence-or-opinion-a-review-of-their-use-and-effects-/5003512.

Published by the BMJ Publishing Group Limited. For permission to use (where not already granted under a licence) please go to http://group.bmj.com/group/rights-licensing/ permissions 